\title{
The taxonomic status of the presumed extinct Singaporean Hoya wallichii (Apocynaceae: Asclepiadoideae)
}

\author{
M. Rodda ${ }^{1}$, N. Simonsson Juhonewe ${ }^{2}$ \& D.J. Middleton ${ }^{1}$ \\ ${ }^{1}$ Herbarium, Singapore Botanic Gardens, National Parks Board, \\ 1 Cluny Road, Singapore 259569 \\ rodda.michele@gmail.com \\ ${ }^{2}$ National Research Institute of Papua New Guinea, P.O. Box 1 - 524, \\ Ukarumpa, Eastern Highlands Province 444, Papua New Guinea
}

\begin{abstract}
After critical study of type material and all available collections, the identity of Hoya wallichii (Wight) C.M.Burton as a species distinct from Hoya campanulata Blume is clarified. Hoya wallichii was previously considered to be endemic to Singapore but had become nationally extinct and consequently globally extinct. This study reveals, however, that it is also found in Peninsular Malaysia and Brunei and, even though it is still nationally extinct in Singapore, it is no longer globally extinct. Hoya campanulata is widespread and locally common in Sundaland but also nationally extinct in Singapore. The two species are fully described and illustrated by line drawings and colour photographs. Two conservation assessments are made, three names are lectotypified, and one name is epitypifed. This paper exemplifies how critical taxonomic understanding is fundamental to meaningful conservation assessments.
\end{abstract}

Keywords. Borneo, Brunei, conservation, epitype, IUCN, lectotype, Malaysia

\section{Introduction}

There are very few endemic plant species in Singapore as almost all species originally described from Singapore have later been found to also occur in Malaysia and/or Indonesia. Ridley (1900) listed 33 species endemic to Singapore. This number was greatly reduced by Kiew \& Turner (2003) who listed only five taxa (plus two endemic hybrids). Of these five, Spatholobus ridleyi King has since been found in Malaysia (specimens in L) and the others are presumed extinct (Kiew \& Turner, 2003; Chong et al., 2009). Due to discoveries made since the publication of Kiew \& Turner (2003) there are now considered to be four extant species of plants endemic to Singapore (Tan et al., 2004; Leong-Škorničková et al., 2014; Leong-Škorničková \& Boyce, 2015). Hoya wallichii (Wight) C.M.Burton, however, has been overlooked in the previous studies on Singaporean endemics, largely due to its unclear identity and subsequent confusion with $H$. campanulata Blume. Hooker (1885) noted that Hoya R.Br. is a 'most difficult genus to describe from dried specimens' because the complex morphology of the corolla and corona is obscured in dried specimens. This is a problem in many groups of plants but for some, including Hoya, closely related species that are readily 
distinguished from fresh or pickled flowers can be extremely difficult to tell apart from herbarium collections alone. Problems of name application in Hoya are not rare. Recent interest in Hoya has focused on phylogeny (Wanntorp et al., 2006a, 2011, 2014) and generic circumscription (Wanntorp et al., 2006b), as well as on specieslevel taxonomy (e.g. Rodda, 2015 and references therein). Typification of Hoya names where necessary, followed by taxonomic revision based on both herbarium specimens and new collections from areas previously poorly collected, are urgently needed to ensure correct name usage in phylogenetic and biogeographic studies.

No collections have been reported from Singapore of plants identified as Hoya wallichii since 1894. If it is a species distinct from Hoya campanulata and is endemic to Singapore this leads to the presumption that it is nationally and globally extinct. In this paper we set out to investigate whether Hoya wallichii is distinct from $H$. campanulata, clarify whether $H$. wallichii is an endemic species in Singapore, and assess whether $H$. wallichii has become globally extinct.

\section{The taxonomic history of Hoya wallichii}

Hoya wallichii was first published as Physostelma wallichii Wight (Wight, 1834). Physostelma Wight, initially a monotypic genus, was separated from Hoya on filament characters. It was also described as having a campanulate corolla, a character already known in Hoya at that time but for only a handful of species, including Hoya campanulata described by Blume (1826) from Java. As more Hoya species were subsequently described, a campanulate or semi-campanulate corolla was observed for many species ranging from Myanmar to Papua New Guinea (Rodda \& Nyhuus, 2009). Despite this, and the lack of any real distinction from Hoya in the filament characters, Physostelma wallichii was transferred to Hoya only relatively recently (Burton, 1996).

Recognition of the similarity between Hoya wallichii and Hoya campanulata began when Decaisne (1844) moved Hoya campanulata into Physostelma as $P$. campanulatum (Blume) Decne. He separated the two species of Physostelma, P. wallichii and $P$. campanulatum, based on differences in the pollen masses whilst suggesting the corolla and corona were similar. Hasskarl (1845), however, designated Hoya campanulata as the type of the monotypic genus Cystidianthus Hassk., leaving P. wallichii in Physostelma. Hasskarl emphasised the similarities of the corolla and corona of Physostelma and Cystidianthus but did not highlight any differences to justify the segregation of the two genera. Bentham \& Hooker (1876) later placed Physostelma wallichii in synonymy of Hoya campanulata without comment. The synonymy was generally accepted by later authors who treated the taxon either as Hoya campanulata (King \& Gamble, 1908; Rintz, 1978) or as Physostelma campanulatum (Hooker, 1885; Boerlage, 1891). Only Ridley (1900) recognised Physostelma wallichii as a separate taxon, but later treated it as a synonym of Physostelma campanulatum (Ridley, 1923). Lastly, Physostelma wallichii was considered a separate taxon by Burton (1996) and the combination Hoya wallichii (Wight) C.M.Burton was made. However, she incorrectly applied the name to material later identified as a new species endemic to Borneo, Hoya 
danumensis Rodda \& Nyhuus. This chain of events shows that researchers have long been unclear whether Hoya wallichii and H. campanulata are distinct from each other and, even when recognised as separate taxa, how the name $H$. wallichii should be correctly applied. For these reasons the endemic status of Hoya wallichii in Singapore and the fact that it appeared to have become extinct were long overlooked.

\section{Distinction between Hoya wallichii and Hoya campanulata}

We have examined the status of these two taxa by examination of original material and other herbarium specimens originally identified as either Hoya wallichii or $H$. campanulata, or were previously unidentified to species, in BM, BO, BRUN, FI, K, KEP, L, P, SAN, SAR, SING and SNP (Thiers, continuously updated). In addition we examined living material from across Sundaland, including recent observations in Peninsular Malaysia. We conclude that Hoya wallichii and H. campanulata are distinct species. Hoya wallichii has solitary flowers (two or three flowers may be present in each inflorescence but only one is open at a time) while $H$. campanulata has convex umbels with up to 30 flowers (Fig. 1); $H$. wallichii has a corolla $3-4 \mathrm{~cm}$ in diameter whereas that of $H$. campanulata is $(1.5-) 2-3 \mathrm{~cm}$ broad; $H$. wallichii has a corona that is purple with kidney-shaped lobes terminating in a short acuminate inner process while that of $H$. campanulata is white or cream-coloured and star-shaped with spreading, almost linear lobes (Fig. 2 A-D).

As the two species are easily distinguished, the confusion between them has primarily been caused by inaccuracies in the literature, starting with the description of Physostelma wallichii. The species was described as bearing 10 filaments and five anthers. The type specimen has typical Hoya filaments that are fused and form a tube, while the five anthers are alternate with the corona lobes. At the time of publication of Physostelma wallichii fewer than 30 species of Hoya had been described, with great variation in corona morphology. It may be possible that Wight interpreted the two guide rails subtending each anther as two filaments. No subsequent authors attempted to explain or justify the distinction between these two genera and, indeed, there is no possible explanation or justification. Eventually Bentham \& Hooker (1876) concluded that there was no distinction between these two genera, combining them into Hoya, but they went too far in synonymising Hoya wallichii under H. campanulata, a surprising action which requires comment given the clear distinction between the two species. We speculate that the diagnostic characters of the corona were not actually examined in detail by Bentham \& Hooker and most other authors. In Kew all herbarium specimens of Hoya wallichii have the corona hidden within the campanulate corolla. There is one specimen on which a detailed illustration of the corona is appended but this specimen was likely not seen by any of these authors as it was only found amongst undetermined material in the general collection (see further discussion below). This apparent lack of observation of the corona is evident in King \& Gamble (1908) and Ridley (1923) because they include specimens of Hoya wallichii and H. campanulata, as well as specimens of two other species only recently described (H. danumensis 
and $H$. mappigera Rodda \& Simonsson), within their single species concept. These species all have thin leaves and a campanulate corolla but are clearly distinguishable in corona characters. Interestingly Ridley is the only author that correctly described Physostelma wallichii as having a red corona (Ridley, 1900), a character that he no longer mentioned in his later treatment (Ridley, 1923).

\section{Typification of Hoya wallichii}

The collections that Wight examined were indicated in the protologue of Physostelma wallichii and were clarified in Noltie (2005) as 'Singapore, Wallich, Wall Asclep. 130[A = Wall. Cat. 8171A. [?Malaya], herb. Finlayson, Wall. Asclep. 130[B = Wall. Cat. 8171B]'. Noltie (2005) did not locate any possible type material in E or K. Wight worked on specimens in his own 'working herbarium' sent from the East India Company (Noltie, 2005). The list of specimens he received can be found in Manuscript 1284, Linnean Society. These specimens usually bear a Herbarium Robert Wight Proper (HRWP) label and were in Wight's private possession until 1871 (Noltie, 2005). The list includes '(Asclep) n 130: (a) Singapore Herb. Wall; (b) Herb Finl.'. Examination of the Hoya specimens in the main herbarium at Kew revealed an undetermined specimen with a HRWP label (Fig. 3B, C). This specimen bears the Wight number ' 130 ' but no 'A' or 'B' and furthermore bears two labels in Wight's handwriting with a manuscript description of Physostelma wallichii and a line drawing of the corona (Fig. 3C). As this specimen is part of the original material and represents a complete and well-preserved specimen belonging to Wight's personal 'working herbarium' it is selected as the lectotype of Hoya wallichii. Two additional specimens labelled Physostelma wallichii are present in the East India Company Herbarium (better known as the Wallich Herbarium, K-W): Singapore, Wallich 8171A and Finlayson in Herb. Wallich $8171 B$, and can be considered syntypes. Both of them have 'Ascl. 130a' (a for Wallich $8171 \mathrm{~A}$; b for Wallich $8171 \mathrm{~B}$ ) pencilled on the lower left corner, probably in C.B. Clarke's hand. Additionally Wallich $8171 \mathrm{~A}$ is also pencilled 'Ascl. 130a' in the upper right corner by an unidentified hand.

It is possible that if the late 19th century and 20th century authors had had access to the HRWP specimen and been able to observe the corona characters Hoya wallichii would not have been synonymised with $H$. campanulata and much of the subsequent confusion would have been avoided.

\section{Implications for conservation}

As noted earlier, even after the existing herbarium material was carefully determined to species, there is no evidence of collections of Hoya wallichii made in Singapore after 1894. All of the recorded localities have been lost to development and recent survey work in still-forested areas of Singapore has not resulted in any new collections. Hoya wallichii favours primary forest where it grows in dappled shade on the ground or on 

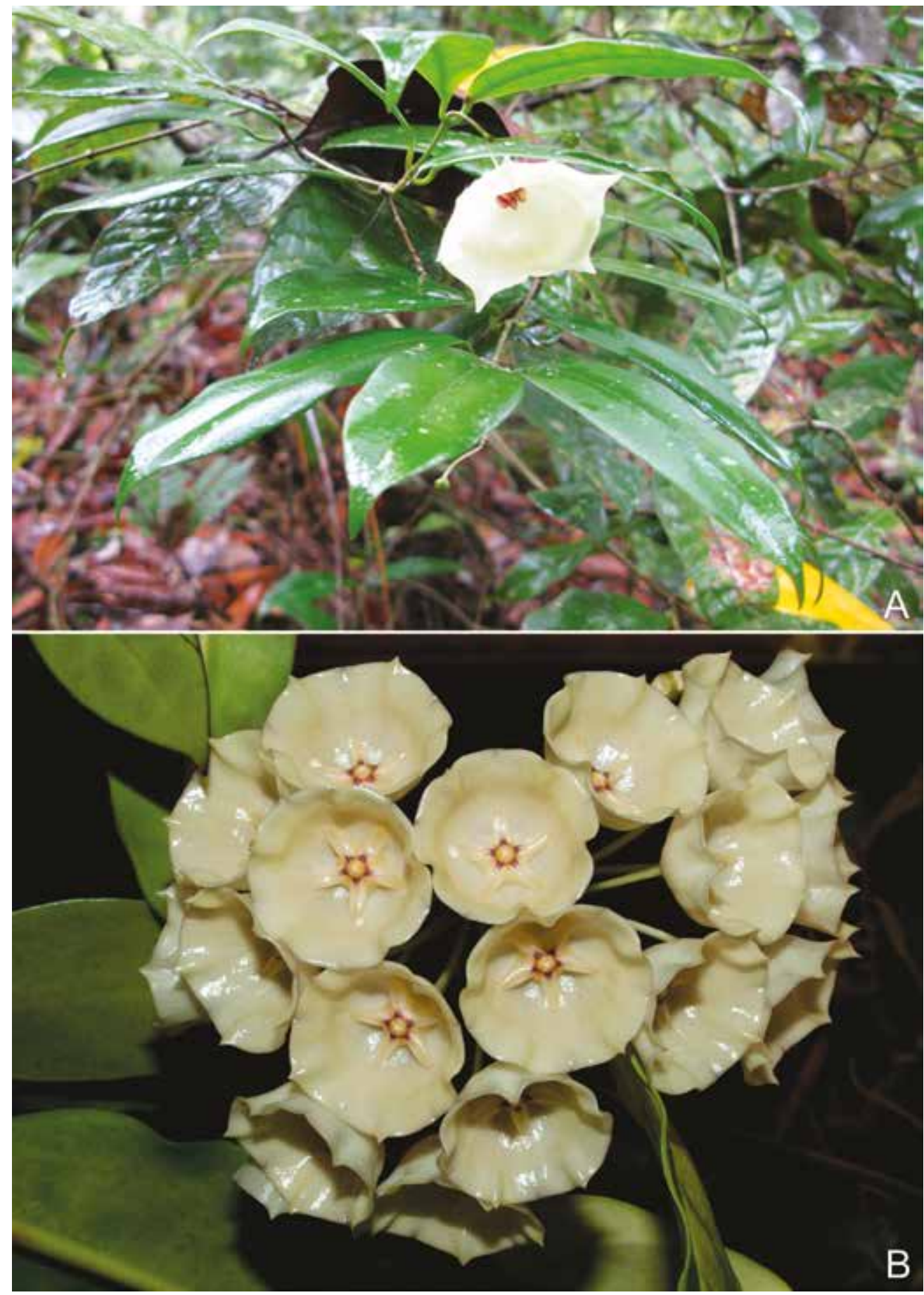

Fig. 1. Comparison between the inflorescences of Hoya wallichii and $H$. campanulata. A. Hoya wallichii in situ in Brunei, with a single flower. B. Hoya campanulata, cultivated at the Singapore Botanic Gardens, with an umbelliform inflorescence. (Photos: A, J. Henrot; B, M. Rodda) 

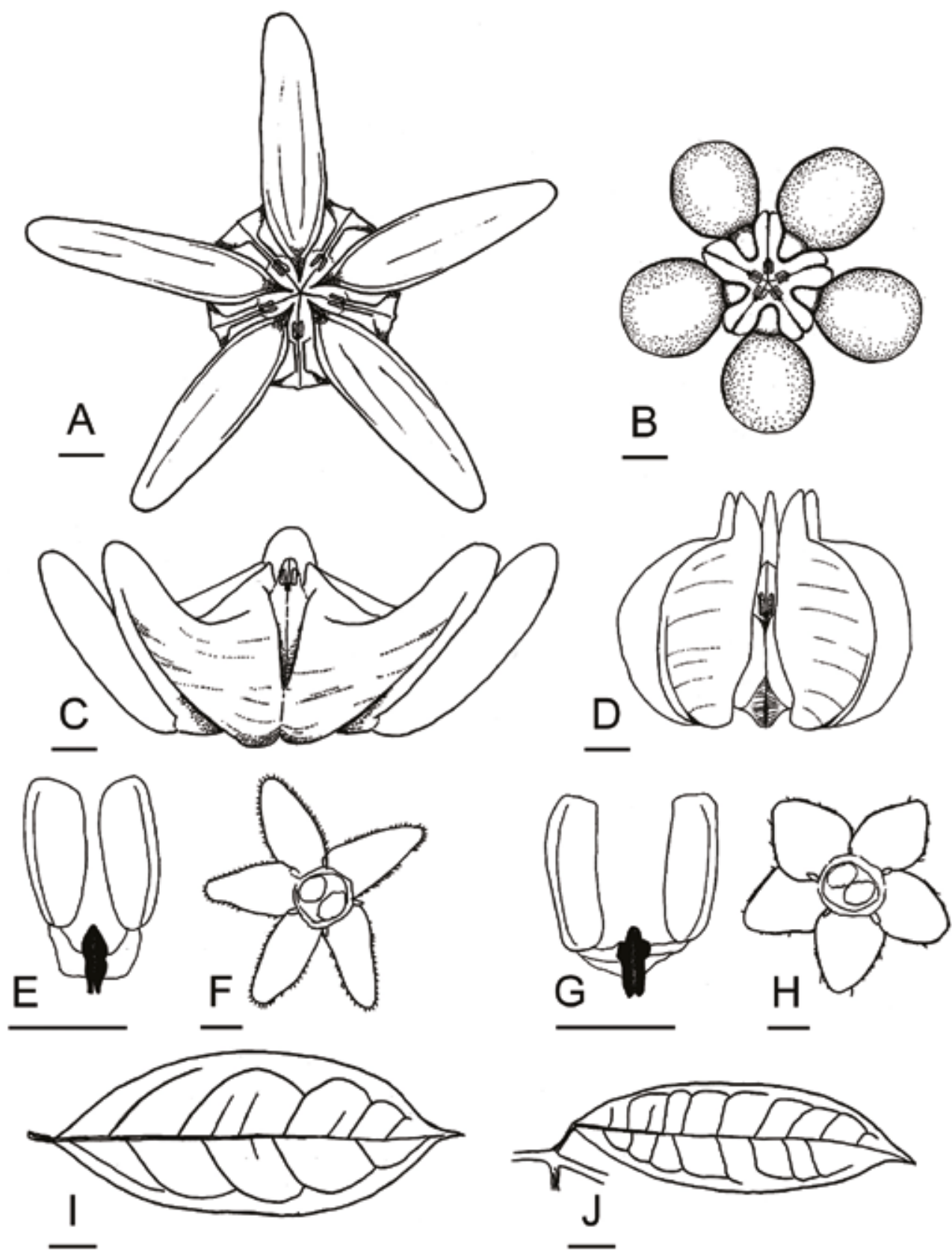

Fig. 2. Morphological comparison between Hoya campanulata (left) and Hoya wallichii (right) A, B. Corona, from above. C, D. Corona, side view. E, G. Pollinarium. F, H. Calyx and ovaries. I, J. Leaf. (A, C, E, F, I Hoya campanulata, from [L0004389]; B, D, G, H, J Hoya wallichii, from [K000449753]. Scale: A, B, C, D, F, H: 1 mm; E, G: $500 \mu \mathrm{m}$; I, J: $1 \mathrm{~cm})$. Drawn by M. Rodda. 


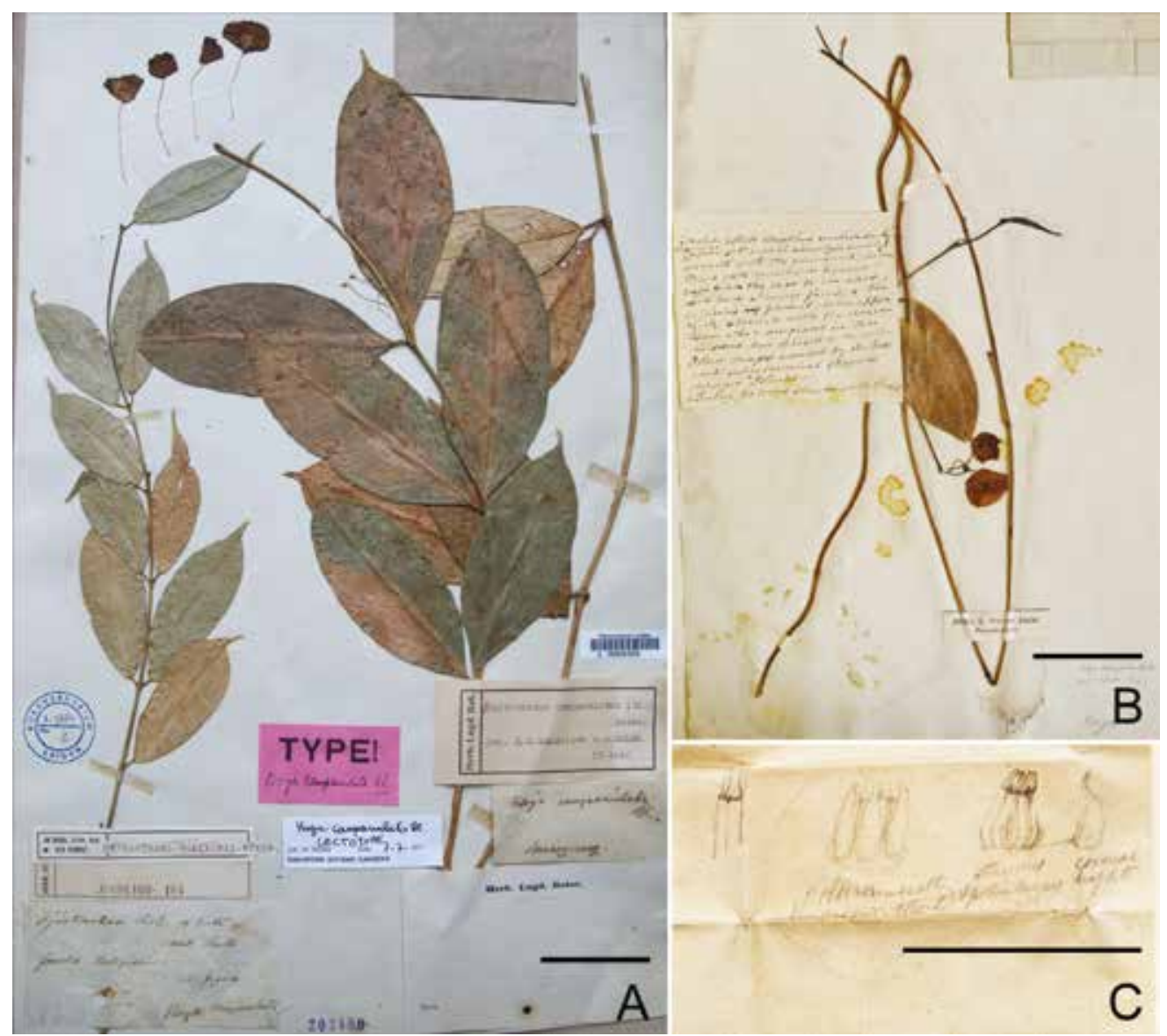

Fig. 3. A. The lectotype of Hoya campanulata in L [L0004389], bearing a label with [Tjunkankan] and [Java] in Blume's hand (label in the lower left corner of the sheet). B. Lectotype of Hoya wallichii in K [ K000449753], bearing a [Herb. R. Wight Prop, Presented 1871] label and pencilled [(Wall Asclep. n.) 130]. The large manuscript label is a description of the species attributed to Wight. C. Drawing of the corona of $H$. wallichii found on the lectotype (Visible folded in the upper right corner of Fig. 3B). Scale: $5 \mathrm{~cm}$. (Photos: M. Rodda, reproduced with the consent of the Royal Botanic Gardens, Kew and Naturalis, Leiden.)

moss-covered rocks. Suitable habitats may still be present in the remaining patches of primary forest in the Central Nature Reserves area and the search for $H$. wallichii and other rare or extinct Hoya species is still on-going. However, a specimen collected in 1939 in Johor, Malaysia (Ngadiman s.n. [SING0120876]), earlier identified as Hoya campanulata, and a collection made in Brunei in 2010 (Henrot, J. JH/509, BRUN), have been identified by us as Hoya wallichii. In addition the species was photographed in Johor in 2012 (Rodda \& Henrot, 2013). We can conclude, therefore, that although Hoya wallichii is extinct in Singapore it is no longer to be considered globally extinct. A formal conservation assessment of Critically Endangered using IUCN (2012) methodology is given below. 
Hoya campanulata is a widespread species in SE Asia, occurring from Peninsular Malaysia to Java but not in Borneo. It occurs up to $1600 \mathrm{~m}$ a.s.1. in Sumatra (de Wilde \& de Wilde-Duyfjes 18595, L), but is largely absent at low altitudes. A formal conservation assessment of Least Concern using IUCN (2012) methodology is given below.

\section{Taxonomic treatment}

Hoya wallichii (Wight) C.M.Burton, Hoyan 18(1:2): 5 (1996). - Physostelma wallichii Wight, Contr. Bot. India 40 (1834). - TYPE: [Singapore] Herb. R. Wight Prop. [Wall Asclep. n.] '130' (lectotype K [K000449753], designated here).

Semi-woody, slender, wiry terrestrial twiner or sub-shrub; latex white. Leafy stems cylindrical, 1.5-3 mm diameter, apically sparsely puberulent, older stems leafless, glabrous with waxy bark. Internodes (1-)2.5-5(-15) $\mathrm{cm}$ long, adventitious roots absent. Leaves opposite, petiolate; petiole flattened or channelled above, rugose below, 5-10 mm long, c. $2 \mathrm{~mm}$ wide, glabrous; lamina chartaceous, flexible, ellipticlanceolate, $4.5-10 \times(1.5-) 2-3(-4) \mathrm{cm}$, widest in the central portion, apex apiculatecuspidate, base cuneate, margin entire, penninerved, main vein depressed on adaxial surface, evident on abaxial surface, secondary veins 5-8 pairs, evident when dry, curved and anastomosing to form an intra-marginal nerve along the edge, branching at $70-80^{\circ}\left(-90^{\circ}\right)$ from main vein. Inflorescences with only one flower fully open at a time; peduncles terete, extra-axillary, perennial, bearing scars of previous flowerings, $1.5-3 \mathrm{~cm}$ long, c. $1.5 \mathrm{~mm}$ wide, glabrous; pedicels terete, $2-4 \times$ c. $1 \mathrm{~mm}$, glabrous, fruit-bearing pedicels more stout, c. $1.5 \mathrm{~mm}$ wide. Calyx c. $4 \mathrm{~mm}$ in diameter, sepals round to rhomboid, $1.5 \times 1-1.5 \mathrm{~mm}$, apex round, margins denticulate, sparsely ciliate; basal gland at the junction between the sepals c. $0.3 \mathrm{~mm}$ long. Corolla campanulate, membranaceous, 3-4 cm in diameter, white to cream-coloured, glabrous; corolla lobes fused with a central free triangular acute tip $5 \times 3 \mathrm{~mm}$. Staminal corona $5-6 \mathrm{~mm}$ high, 6-7 mm diameter, purple, lobes erect, kidney-shaped, c. $5 \mathrm{~mm}$ high, c. $2 \mathrm{~mm}$ wide, basally broadened into a swollen process with basal revolute margins, apically forming a single acuminate appendage c. $1.2 \mathrm{~mm}$ long, extending c. $2 \mathrm{~mm}$ above the anthers. Pollinarium (all measurements approx.) $800 \mu \mathrm{m}$ long, pollinia oblong, $600 \times$ $200 \mu \mathrm{m}$, apex and base round, corpusculum $300 \times 170 \mu \mathrm{m}$, caudicles $200 \mu \mathrm{m}$ long. Ovary bottle-shaped, c. $2 \mathrm{~mm}$ long. Fruits cylindrical follicles, developing singly, 12-20 cm long, 5-7 mm in diameter; seeds comose, spindle-shaped, 7-8 × c. $2 \mathrm{~mm}$.

Distribution. Brunei, Peninsular Malaysia (Johor), Singapore (extinct).

Additional specimens examined. SINGAPORE: sin. loc., 1821 or 1822 , Wallich, $N$. $8171 \mathrm{~A}$ (syntype K-W [K000438428]); sin. loc., 4 Nov 1889, Ridley, H.N. 2604 (BM); sin. loc., ex Hb. Finlayson, Wallich, N. 8171B, (syntype K-W [K000438429]); Kranji: 29 Nov 1889, Goodenough, J.S. 2684 (SING [SING0120837]); 8 Jan 1890, Ridley, H.N. s.n. (SING 
[SING0120836]); Tampines: River, Feb 1894, Ridley, H.N. s.n. (SING [SING0012208]); Sarimbun: 2 Oct 1894, Mat 6691 (SING [SING0012207]).

BRUNEI: Belait: Labi, 2 Oct 2010, Henrot, J. JH/509 (BRUN).

MALAYSIA: Johor: Pontian, Pengkalan Raja, 25 Jun 1939, Ngadiman, I. s.n. (SING [SING0120876]).

Provisional IUCN conservation assessement. Critically Endangered (CR B2ab(iii)). Previously believed to be endemic to Singapore and presumed extinct, it is now only known from two quite disjunct localities in Johor and Brunei. In Johor it is known from a collection from 1939 in Pengkalan Raja, too long ago to be considered in a new conservation assessment without confirmation the species still occurs there, and a recent photograph. The condition of the locality in Brunei is uncertain but the locality of the recently photographed plant in Johor is on the edge of a forest park that is quite disturbed.

Hoya campanulata Blume, Bijdr. 1064 (1826). - Physostelma campanulatum (Blume) Decne. in A.DC., Prod. 8: 633 (1844). - Cystidianthus campanulatus (Blume) Hasskarl, Tijdschr. Natuurl. Gesch. Physiol. 10: 125 (1843). - TYPE: Indonesia, Java, 'ex horto, mento septembre, Tjunkankan, Burangarang' (lectotype L [L0004389], designated here).

Cystidianthus laurifolius Blume, Mus. Bot. 1(4): 57 (1849). - Hoya cystiantha Schltr., Bot. Jahrb. Syst. 50: 127 (1913). - TYPE: Indonesia, Sumatra, 'Cystidianthus laurifolius Bl', Korthals s.n.. (lectotype L [L0004387], designated here; isolectotype L [L0004388]). - EPITYPE: Indonesia, Sumatra, Ketambe, Aceh Province, South edge of Taman Gunong Leuser, Green, T. 99009 (epitype BISH [BISH1016621], designated here).

Semi-woody, slender, wiry terrestrial or epiphytic twiner or sub-shrub; latex white. Leafy stems cylindrical, 1.5-3 mm diameter, apically sparsely puberulent, older stems leafless, glabrous, rugose. Internodes $3-5(-18) \mathrm{cm}$ long, adventitious roots absent, unless in direct contact with substrate. Leaves opposite, petiolate; petiole channelled above, rugose below, 4-8 $\mathrm{mm}$ long, c. $2 \mathrm{~mm}$ wide, glabrous; lamina chartaceous, flexible, elliptic-lanceolate, $5-7(-12) \mathrm{cm}$ by $(2-) 3-5 \mathrm{~cm}$, widest in the central portion, apex apiculate-cuspidate, base cuneate, margin entire, penninerved, main vein depressed on adaxial surface, evident on abaxial surface, secondary veins 4-6(-8) pairs evident when dry, curved and anastomosing to form an intra-marginal nerve along the edge, branching at $50-60^{\circ}$ from main vein. Inflorescences pseudo-umbelliform, convex, positively geotropic, up to 20-flowered; peduncles terete, extra-axillary, perennial, bearing scars of previous flowerings, about 1-2(-5) cm long, c. $1.5 \mathrm{~mm}$ wide, glabrous; pedicels terete, $3-4 \mathrm{~cm}$ by c. $1 \mathrm{~mm}$, glabrous, fruit-bearing pedicels more stout, up to $2 \mathrm{~mm}$ wide. Calyx c. $5 \mathrm{~mm}$ in diameter, sepals lanceolate to oblong, 2-2.5 $\times 1-1.5$ $\mathrm{mm}$, apex rounded, margins ciliate; basal gland at the junction between the sepals c. 
$0.4 \mathrm{~mm}$ long. Corolla campanulate, membranaceous, (1.5-)2-3 cm in diameter, white to cream-coloured, sometimes yellow or pink-flushed, glabrous; corolla lobes laterally fused with a central free acute triangular tip, $2 \times 2 \mathrm{~mm}$. Staminal corona star shaped, 3-4 mm high, 7-10 mm diameter, white, corona lobes boat-shaped, terete, $4.5-5.5 \mathrm{~mm}$ long, 1.5-2 mm broad, basally presenting revolute margin, outer process ascending; basal process laterally spreading, when viewed perpendicularly to the corona forming a disk of 3-4 mm radius. Pollinarium (all measurements approx.) $1 \mathrm{~mm}$ long, pollinia oblong, $800 \times 230 \mu \mathrm{m}$, apex and base rounded to truncate, corpusculum $280 \times 130$ $\boldsymbol{\mu m}$, caudicles $150 \boldsymbol{\mu m}$ long. Ovary bottle-shaped, c. $1.5 \mathrm{~mm}$ long. Fruits cylindrical follicles, developing singly but up to 5 for each inflorescence, $12-18 \mathrm{~cm}$ long, 5-7 mm in diameter; seeds comose, spindle-shaped, 4-5 × c. $1 \mathrm{~mm}$.

Distribution. Indonesia (Java, Sumatra), Peninsular Malaysia, Singapore (extinct).

Additional specimens examined. Unlocalised, Cult. Kew, 'Bot. Mag. T 4545' (K); label unreadable (L [L0796650]), (L [L0796647]).

SINGAPORE: Tampines: November 1893, Almeida, E.D. s.n. (SING [SING0012210]).

MALAYSIA: Unknown locality: King's collector 2587, fragment (K); Wray, L.W. 3139, fragment (K); Wray, L.W. 4041, fragment (K). Selangor: Ulu Gombak, 17 mile, 25 Oct 1937, Md. Nur 34219 (A n.v., P [P00700460], SING); Sungai Rangkap, 500 ft, 23 May 1976, Rintz, R.E. RER58 (KEP [KEP160389]); Sungai Semangkok, $2200 \mathrm{ft}, 27$ Sep 1976, Rintz, R.E. RER124 (KEP [KEP160391]); Sungai Semangkok, 2700 ft, 25 Sep 1976, Rintz, R.E. RER119 (KEP [KEP160390]); 15 mile Sungai Gombak, River edge in lowland forest, $700 \mathrm{ft}$, Rintz, R.E. RER22 (L [L0796665], KEP [KEP160393]); Klang Gates, 22 Jul 1927, Strugnell, E.F. 13033 (KEP [KEP160399]). Perak: Larut, 300-380 ft, Jan 1883, King, G. 3849 (K); Thaiping Hills, Feb 1900, Ridley, H.N. s.n. (SING [SING0120878]); Tenok Road, Tapah, Ridley, H.N. s.n. (SING). Negeri Sembilan: Jelebu, Berembun F.R., Jeram Toi, Riverside trail, Across river, $2^{\circ} 51^{\prime} 40^{\prime \prime} \mathrm{N} 102^{\circ} 00^{\prime} 58^{\prime \prime} \mathrm{E}, 332 \mathrm{~m}$ a.s.1., 10 Apr 2008, Yat, T.L. FRI57949 (KEP [KEP159153]). Malacca: 1898, Ridley, H.N. 9712 (SING).

INDONESIA: Java sin. loc.: s.d., s.coll. 'misit Blume', 1836 (P [P00700459]); 25 Jun 1848, Zollinger, H. s.n. (P [P00700458]); s.d., Blume s.n. (L [L0796663]); s.d., s.coll. s.n. (L [L0796664]); 1878, s.coll. s.n. (L [L0796649]); s.d., s.coll. s.n. (L [L0796652]); ex herb. Blume (L [L0796648]); s.d., s.coll. s.n. (L [L0796651]); s.d., s.coll. s.n. (L [L0796653]). West Java: Buitenzorg, 'Kikandel', Lecomte, P.H. \& Finet, A. s.n. (P [P00218897]); Buitenzorg, 1 Sep 1926, herb d'Alleizette 4853 (L [L0796646]); 'ex horto, mento septembre, Tjunkankan Burangarang' (L [L0004389]); ‘Tjunkankan' (L [L0004390]); Preanger, Guenueng Beser Tjigagap, 1000 m a.s.l., 6 Nov 1917, Bakhuizen Van den Brink R.C. 2946 (L [L0796655]); Preanger, Tjadas Malang, 1000 m, 25 Mar 1917, Bakhuizen Van den Brink R.C. 2896 (L [L0796656]); Batavia, 2 Mar 1929, Bakhuizen Van den Brink R.C. 7176 (L [L0796654]); Tjiandjun Distr. Gunung Boser near Tjidadep, 1100 m a.s.1., May 1968, Kostermans, A.J.G.H. s.n. (L [L0794340]). Sumatra sin. loc.: s.d., s.coll. s.n. (syntype L [L0004386]); s.d., Forbes, H.O. 2257, fragment (K); s.d., s.coll. s.n. (L [L0796657]); s.d., s.coll. s.n. (L [L0796658]); s.d., s.coll. s.n. (L [L0796659]); s.d., Wray, L.W. 1841 (SING [SING0120872]). Aceh: Gajolanden, Goempang to Kongke, c. 800 m., 12 Mar 1937, van Steenis, C.G.G.J. 9759 (K, L [L0796660]); Gunung Leuser Nature Reserve, Camp Simpang and vicinity, 3-5 km upstream Lau Ketambe, c. $33 \mathrm{~km}$ NW of Kutatjane, 20 Jul 1972, de Wilde, W.J.J.O. \& de Wilde-Duyfjes, B.E.E. 13837 (L [L0794352]); Gunung Leuser Nature Reserve, Ketambe, valley of Lau Alas, near tributary of Lau Ketambe, c. 
$35 \mathrm{~km}$ NW of Kutatjane, 200-400 m alt., de Wilde, W.J.J.O. \& de Wilde-Duyfjes, B.E.E. 12166 (L [L0794348]), 12167 (L [L0794347]); Gunung Leuser Nature Reserve, Ketambe, valley of Lau Alas, near tributary of Lau Ketambe, c. $35 \mathrm{Km}$ NW of Kutatjane, 200-400 m alt., 29 May 1972, de Wilde, W.J.J.O. \& de Wilde-Duyfjes, B.E.E. 12455 (L [L0794347]); P. T. Hargas logging concession, c. $2^{\circ} 43^{\prime} \mathrm{N} 97^{\circ} 34^{\prime}$, c. $10 \mathrm{~m}$ alt., 3 Aug 1985, de Wilde, W.J.J.O. \& de WildeDuyfjes, B.E.E. 20578 (L [L0794360]); Upper Mamas River valley expedition, c. $18 \mathrm{~km} \mathrm{~W}$ of Kutacane, c. $3^{\circ} 25^{\prime} \mathrm{N} 97^{\circ} 40^{\prime} \mathrm{E}, 1600 \mathrm{~m}$ alt., 22 Jun 1979, de Wilde, W.J.J.O. \& de Wilde-Duyfjes, B.E.E. 18595 (L [L0794349]). West Sumatra: near Mount Sigirik within Bukit Sebelah nature reserve, 500 m alt., 15 May 1983, Laumonier, Y. TFB 4379 (L [L0794350]); Taram, East of Pajakumbuh, region of river Tjampo, 500-1000 m alt., Mundji 340 (L [L0796661]); Padang Highlands, 1200 m, 10 Oct 1919, Batten Pool, A.H. s.n. (SING [SING0121892]).

Provisional IUCN conservation assessement. Least Concern (LC). This species is widespread and, despite the paucity of very recent collections, is still locally common and not under any known threat (MR pers. obs.).

Notes. Blume (1826) did not cite any specimens in the protologue of Hoya campanulata but specified 'in fruticetis montanis Javae occidentalis', flowering 'toto anno' and gave the local name as 'Tjunkankan'. A specimen labelled Hoya campanulata Blume [L0004389], bearing a label with [Tjunkankan] and [Java] in Blume's hand has been found in L (Fig. 3). This is the only specimen found with elements from the protologue. The specimen is well preserved with both leafy shoots and flowers and is therefore designated as the lectotype of Hoya campanulata.

The original description of Cystidianthus laurifolius Blume, later Hoya cystiantha Schltr., is similar to $H$. campanulata in all aspects except with smaller flowers (Blume, 1848). Hoya campanulata flowers are very variable in size across its range, without any other morphological discontinuity, and therefore $H$. cystiantha is here treated as a synonym of $H$. campanulata. Cystidianthus laurifolius (and its replaced synonym Hoya cystiantha) was neotypified by Green (2011) where he stated that no extant original material could be traced. Blume (1849) only mentioned 'In Sylvis Sumatris'. In L we found three specimens from Sumatra annotated in Blume's handwriting as Cystidianthus laurifolius. Two of these were collected by Korthals [L0004387 and L0004388], and are likely to be duplicates, while the third is from an unknown collector [L0004386]. We believe these to be original material. All three specimens lack complete flowers but [L0004387] has an intact calyx and, being the least sterile specimen, is therefore selected as lectotype for the name. As the lectotype is nevertheless almost sterile we select Green's neotype (Green 99009 [BISH1016621]) as epitype for Cystidianthus laurifolius Blume.

ACKNOWLEDGEMENTS. Jana Leong-Škorničková was the handling editor for this manuscript. This research received support from the National Parks Board (Singapore) that sponsored herbarium visits in Asia and Europe (MR \& DJM). We thank the curators of the BM, BO, BRUN, FI, K, KEP, L, P, SAN, SAR, SNP and SING herbaria for allowing access and/or for providing high quality images of herbarium specimens. We thank J. Henrot for providing 
photographs of Hoya wallichii in situ in Brunei. Two anonymous reviewers and Jana LeongŠkorničková are thanked for suggesting improvements to the manuscript.

\section{References}

Bentham, G. \& Hooker, J.D. (1876). Physostelma. In: Bentham, G. \& Hooker, J.D. (eds) Genera Plantarum 2. P. 777. London: L. Reeve \& Co.

Blume, C.L. (1826). Hoya. In: Blume, C.L. (ed) Bijdr. Fl. Ned. Ind. 16. Pp. 1062-1065. Batavia: Ter Lands Drukkerij.

Blume, C.L. (1848). Asclepiadeae. In: Blume, C.L. (ed) Rumphia 4. Pp. 29-35. C.G. Leiden: Sulpke.

Blume, C.L. (1849). Cystidianthus. In Blume, C.L. (ed) Mus. Bot. 1. P. 57. Lugduni-Batavorum: apud E.J. Brill (Ex typographeo J.G. la Lau)

Boerlage, J.G. (1891). Asclepiadaceae. In: Boerlage, J.G. (ed) Handl. Fl. Ned. Ind. 2. Pp. 401-442. Leiden: E.G. Brill.

Burton, C.M. (1996). A tentative alternative arrangement of Hoya sections. Hoyan 18(1:2): $2-6$.

Chong, K.Y., Tan, H.T., \& Corlett, R.T. (2009). A Checklist of the Total Vascular Plant Flora of Singapore: Native, Naturalised and Cultivated Species. 273 p. Singapore: Raffles Museum of Biodiversity Research, National University of Singapore.

Decaisne, J. (1844). Hoya. In: De Candolle, A. (ed) Prodromus 8. Pp. 634-640. Paris: Fortin, Masson et sociorum.

Green, T. (2011). Designation of a neotype for a species of Hoya from Sumatra: Hoya cystiantha Schlechter. Asklepios 111: 27-28.

Hasskarl, J.C. (1845). Plantarum Javanicarum aut Novarum aut Minus Cognitarum Adumbrationes. Flora 16: 225-256.

Hooker, J.D. (1885). Physostelma. In: Hooker, J.D. (ed) The Flora of British India 4. Pp. 6263. London: L. Reeve \& Co.

IUCN (2012). IUCN Red List Categories and Criteria: Version 3.1. Second edition. Gland, Switzerland and Cambridge, UK: IUCN.

Kiew, R. \& Turner, I.M. (2003). Are any plants endemic to Singapore? Gard. Bull. Singapore 55: $173-184$.

King, G. \& Gamble, J.S. (1908). Hoya. In: King, G. \& Gamble, J.S. (eds) Flora of the Malayan Peninsula. J. Asiat. Soc. Bengal, Pt. 2, Nat. Hist. 74:559-580.

Leong-Škorničková, J. \& Boyce, P.C. (2015). Hanguana in Singapore demystified: an overview with description of three new species and a new record. Gard. Bull. Singapore 67: 1-28.

Leong-Škorničková, J., Thame, A. \& Chew, P.T. (2014). Notes on Singapore native Zingiberales I: A new species of Zingiber and notes on the identities of two further Zingiber taxa. Gard. Bull. Singapore 66: 153-167.

Noltie, H.J. (2005). The Botany of Robert Wight. Regnum Vegetabile 145. Ruggell: A.R.G. Gantner Verlag.

Ridley, H.N. (1900). The Flora of Singapore. J. Straits Branch Roy. Asiat. Soc. 33: 27-196.

Ridley, H.N. (1923). Hoya. In Ridley, H.N., The Flora of the Malay Peninsula 2. Pp. 393-402. London: L. Reeve \& Co.

Rintz, R.E. (1978). The Peninsular Malaysian species of Hoya (Asclepiadaceae). Malayan Nat. J. 30: 467-522.

Rodda, M. (2015). Two new species of Hoya R.Br. (Apocynaceae, Asclepiadoideae) from Borneo. PhytoKeys 53: 83-93. 
Rodda, M. \& Henrot, J. (2013). Hoya wallichii: Confused, exinct, and rediscovered. Gardenwise 41: 18-19.

Rodda, M. \& Nyhuus, T. (2009). Hoya danumensis, a new species of Hoya (Apocynaceae, Asclepiadoideae) from Borneo. Webbia 64: 163-167.

Tan, B.C., Ho, B.-C. \& Seah, B.K.-B. (2004). Two new moss species, Trichosteleum fleischeri and Splachnobryum temasekensis, from Singapore. J. Hattori Bot. Lab. 96: 1-7.

Thiers, B. (continuously updated). Index Herbariorum: A global directory of public herbaria and associated staff. New York Botanical Garden's Virtual Herbarium. http://sweetgum. nybg.org/science/ih/ (accessed on 24 Jun. 2016)

Wight, R. (1834). Contributions to the Botany of India. London: Parbury \& Co.

Wanntorp, L., Kocyan, A. \& Renner S.S. (2006a). Wax plants disentangled: A phylogeny of Hoya (Marsdenieae, Apocynaceae) inferred from nuclear and chloroplast DNA sequences. Molec. Phylogenet. Evol. 39: 722-733.

Wanntorp, L., Kocyan, A., Van Donkelaar, R. \& Renner, S.S. (2006b). Towards a monophyletic Hoya (Marsdenieae, Apocynaceae): Inferences from the chloroplast trnL region and the rbcL-atpB spacer. Syst. Bot. 31:586-596.

Wanntorp, L., Gotthardt, K. \& Muellner, A.N. (2011). Revisiting the Wax Plants (Hoya, Marsdenieae, Apocynaceae): Phylogenetic tree using the matK gene and psbA-trnH intergenic spacer. Taxon 60: 4-14.

Wanntorp, L., Grudinski, M., Forster, P.I., Muellner-Riehl, A.N. \& Grimm, G.W. (2014). Wax plants (Hoya, Apocynaceae) evolution: Epiphytism drives successful radiation. Taxon 63: 89-102. 
